\title{
MIKROALGA SZUSZPENZIÓK MINT NÖVÉNYI TÁPSZEREK
}

\section{MICROALGAE SUSPENSIONS AS PLANT NUTRIENTS}

\author{
Hodai Zoltán ${ }^{1}$, Rippelné Pethő Dóra ${ }^{2}$, Horváth Géza ${ }^{3}$, Hanák László $^{4}$, Bocsi Róbert ${ }^{5}$ \\ Pannon Egyetem:' Mérnöki Kar, Vegyipari Müveleti Intézeti Tanszék, H-8200, Ma- \\ gyarország, Veszprém, Egyetem utca 10. Telefon: +36(88)624-132, Fax: \\ +36(88)642-446, H-8201 Veszprém, Pf. 158. \\ ${ }^{1}$ hodaiz@almos.uni-pannon.hu \\ 2pethod@almos.uni-pannon.hu \\ ${ }^{3}$ horvathg@almos.uni-pannon.hu \\ 4hanakl@almos.uni-pannon.hu \\ 5bocsirobert@almos.uni-pannon.hu
}

\begin{abstract}
Plant nutrients are essential to growth plants in the appropriate way. Traditional fertilizers can redound significant yield growth in short term, but it can not use for long term because of the adverse effects on soil fertility. Eco-friendly formulas can be produced by using microalgae suspensions which can help the nutrient intake and accelerate even the yield formation and maturation. The microalgae based foliar fertilizers are suitable efficient herbal nutrients because of their micro and macro elements; but they are good plant and soil preparation, too. They contain the nutrients in the best form of usable and accessible compounds. But the industrially grown algae suspensions mean challenge for the producers on the section of energy and storability. Industrial demands arised by setting of the producing operations which can give facilities for economical storing without degradation. Task is to research and set the preservation and storing of microalgae suspensions for industrial algae growing systems. The produced, amplified cultures should be storable in the most economical ways by preserving the value of the product. Based on our experiments can be increased the duration of storage can be increased eight fold.
\end{abstract}

Keywords: microalgae, foliar fertilizer, plant nutrient, storage, pectin

\section{Összefoglalás}

A növények növekedéséhez, egészséges fejlödéséhez nélkülözhetetlenek a növényi tápszerek. A hagyományos mütrágyák használatával rövidtávon jelentős hozamnövekedés érhető el, de ez hosszú távon nem tartható fenn talaj termékenységre gyakorolt kedvezötlen hatása miatt. Környezetkímélö növényi tápok állíthatóak elő mikroalga szuszpenziók felhasználásával, melyek a növények számára elösegítik a tápanyagfelvételt, továbbá a termésképződés és a termésérés is hamarabb zajlik le. A mikroalga-bázisú lombtrágyák nem csupán a beltartalmi, kísérő makro- és mikro-elemeknek (NKP, nyomelemek...) köszönhetően alkalmas és rendkívül hatásos növényi tápanyagok, hanem növényvédö szer és talajjavító készítmények is egyben. A növények számára szükséges tápkomponenseket jobban hasznosítható és hozzáférhetőbb vegyületek formájában tartalmazzák. Az iparilag termesztett alga szuszpenziók azonban kihívások elé állítják a termék elóállítóit egyrészt energetikai, másrészt a termék tárolhatósági területein. Ipari igények merültek fel a termesztéshez szükséges müvelet illesztése terén, ami lehetőséget nyújt a termék gazdaságos és minőségromlás nélküli tárolására. Feladat a mikroalga szuszpenzió tartósításának, tárolhatóságának kutatása és illesztése ipari algatermesztő rend- 
szerekhez. A megtermelt, felszaporított tenyészetek minél gazdaságosabban raktározhatóak legyenek, a termék értékének megőrzésével. Eddigi kísérletek alapján nyolcszorosára növelhető a tárolás időtartama.

Kulcsszavak: mikroalga, lombtrágya, növényi táp, tárolás, pektin

\section{Bevezetés}

A mütrágyák nagy mennyiségü használata a kezdeti kedvező hatások mellett világszerte komoly ökológiai degradációt okoznak, amely az óceánok pusztulásához, talaj meddőségéhez és a biodiverzitás csökkenéséhez vezet. Szembe kell néznünk nem csak olyan kihívásokkal, mint a mezőgazdasági termelés növelése, hanem a globális éghajlatváltozással is. Ez utóbbi azzal is fenyeget, hogy bizonyos területeken a termelékenység jelentősen csökkenhet, szélsőséges esetben 0-ra redukálódhat. Már a jelenben indokolt innovatív technológiák kutatása, azok fejlesztése, hogy növelni lehessen a mezőgazdasági hozamokat amellett, hogy a ráfordítások minimalizálódjanak és a környezet terhelése is mérséklődjön. A mikroalgák biotrágyaként való alkalmazása egy lehetséges, megfelelő megoldás lehet a fent említett problémákra [1].

Tekintettel arra, hogy a mikroalga szuszpenziók nagy mennyiségben tartalmaznak mikro-, illetve makroelemeket, azok növények számára jól hasznosítható formában szintén kívánatossá teszik biotrágyaként való használatra. Továbbá növényekhez hasonló hormonokat termelnek, ami növeli a növényzetnek nem csupán bimassza-, termék hozamát, hanem ellenállóbbá is teszi őket. Számos tanulmány született a mikroalgák biotrágyakénti való használta, a tápanyagfelvétel és a terméshozam növekedése kapcsán [2-7].

\section{Tartósítási, tárolási lehetőségek}

Mikroalga szuszpenzió minőségromlás nélküli eltárolhatósága $\mathrm{kb}$. 1 hét, amit a gyakorlati hasznosíthatósághoz növelni szükséges. Tárolására a teljesség igénye nélkül az alábbi lehetőségek állnak rendelkezésre: kiroprezerváció, szárítás, védőgázos tartósítás, alginát gyöngyben [8] való megkötés. Kutatásaink során ez utóbbi technológia tűnik jelenleg energetikailag elfogadhatónak, a sejtek jelentős minőségromlásának elkerülése mellett. A mikroalgákat tartalmazó gél gyöngyök elöállításához az algináthoz hasonló tulajdonságokkal rendelkezö, bizonyos szempontok szerint kedvezőbb pektint vizsgáltuk, mint alkalmazható gélesítő anyag. A pektin hidrokolloid és a vízmegkötő képessége miatt alkalmazzák sürítő és gélesítő anyagként. Az iparban gyümölcslevek gyártása során visszamaradt alma törkölyből és citrusok héjából nyerik. A nátriumalgináthoz hasonlóan, képes kölcsönhatásba lépni a $\mathrm{Ca}^{2+}$-al komplex képződése közben, térbeli átrendeződést indukálva. A nátriumalginátal megegyező tulajdonsága és jó hozzáférhetősége (élelmiszeripari melléktermék) miatt vizsgáljuk, mint gélesítő anyagot.

\section{Kísérleti rész}

\subsection{Gélben történő megkötés}

Kereskedelmi forgalomban kapható „Nature Cookta” 100\% citruspektint használtunk. Előkísérleteknél a különböző minőségü mikroalga szuszpenziót sürítés nélkül alkalmaztuk. Az oldat, amelyből a gyöngyöket készítettük $350 \mathrm{~cm}^{3}$ mikroalga szuszpenzió $\left(\sim 2 \mathrm{~g} / \mathrm{dm}^{3}\right), 150 \mathrm{~cm}^{3}$ desztillált víz, amihez $3 \mathrm{~V} / \mathrm{V} \%$ pektint adagoltunk. Ez $15 \mathrm{~g}$ pektin por tartalmat jelent. A $150 \mathrm{~cm}^{3}$ desztillált vizet és a $15 \mathrm{~g}$ pektin port összemértük, homogenizáltuk, majd hőközléssel $\left(60{ }^{\circ} \mathrm{C}\right)$ és folyamatos keverés mellett homogén pektinoldatot készítettünk (30 min). Miután szobahőmérsékletre hült, hozzáad- 
tuk a tárolandó szuszpenzióhoz. Szabályozott csepegtetéssel $\left(250 \mathrm{~cm}^{3}\right) \quad 3,3 \mathrm{~g} / \mathrm{dm}^{3}$ $\mathrm{CaCl}_{2}$ oldatba juttatva kialakítottuk a gömb geometriát. Leszürtük a gyöngyöket és desztillált vízzel átmostuk. $1 \mathrm{dm}^{3}$-es tároló palackokba töltve a megtisztított gyöngyöket kezdődött a tárolási kísérlet.

\subsection{Tárolás}

A palackokat két különböző hőmérsékleten tároltuk. $4{ }^{\circ} \mathrm{C}$-on termosztált tároló szekrényben és tároló raktárban $\left(\sim 16^{\circ} \mathrm{C}\right)$. Visszaoldást megelőzően a minták tárolási ideje $4^{\circ} \mathrm{C}$-on 5 hét volt, a raktárban pedig 4 hét. Ez alatt heti rendszerességgel vizsgáltuk a gyöngyök fizikai jellemzőit (fotometria, átlagos gyöngy átmérő, elfolyósodás valamint érzékszervi vizsgálatok /szín, szag/). A visszaoldási kísérleteknek az időpontjában $\left(\mathrm{a} 4^{\circ} \mathrm{C}\right.$-os minták esetén a tárolás 35. napján, a raktárban tárolt minták esetén a tárolás 28. napján) a gyöngyök állapotában releváns változást nem tapasztaltunk.

\subsection{A gyöngyök fizikai tulajdonságai- nak mérése}

A gyöngyök méretét Mitutoyo Abslute AOS Digimatic digitális tolómérővel végeztük. A gyöngyök spontán elfolyósodásának mértékét tömegméréssel határoztuk meg. A tárolás során elfolyósodott és épen maradt gyöngyök tömegét mértük, majd desztillált vizes mosással eltávolítottuk a gyöngyök felületéről a már elfolyósodott részt. Ezután az épen maradt gyöngyöket lecsepegtetést követően mértük vissza a tömegüket. A két mérés különbsége adta az elfolyósodás mértékét.

\subsection{A gyöngyök visszaoldása}

$100 \mathrm{db}$ gyöngyöt $6 \mathrm{~cm}^{3} 5 \mathrm{~m} / \mathrm{m} \%$-os nátrium-hexametafoszfát desztillált vizes oldatával $24 \mathrm{~cm}^{3}$ módosított BG-11 típusú tápoldatban oldottuk $12 \mathrm{~h}$ alatt.

\section{Kísérlet eredményei}

\subsection{Elfolyósodás vizsgálata}

Eltárolás pillanatában a gyöngyök szilárdak és rugalmasak voltak. A $4{ }^{\circ} \mathrm{C}$-on tárolt gyöngyöknél a 4. hétig nem észleltünk változást. Az 5. héten a gyöngyök felületének puhulását tapasztaltuk, de folyós állagú rész még nem volt a gyöngyök térközében. A 6. héten jelentős elfolyósodás volt megfigyelhető. Ekkor tömegméréssel számosítva az elfolyósodott tömeg a kiindulási tömeg 52\%-a volt. A 7 . hétre a gyöngyök egésze híg, folyós géllé degradálódott.

A raktárban $\left(16{ }^{\circ} \mathrm{C}\right)$ tárolt mintán az 5 . hétig nem észleltünk jelentős minőségi változást. A 6. héten a gyöngyök felületének puhulását figyeltük meg, de folyós állagú közeg még nem volt tapasztalható a gyöngyök térközében. A 7. héten jelentős elfolyósodást tapasztaltunk. Ekkor az elfolyósodott tömeg a kiindulási tömeg $21 \%$-a volt. A 8 . hétre a gyöngyök egésze degradálódott.

(A vizsgált 8 hét alatt a minták minősége, illata és színe nem változott, a teljes degradációt követő időszakban sem.)

\subsection{Sejtek életképességének megha- tározása}

A gyöngyök visszaoldásával kapott szuszpenziókat termesztő foto-bioreaktorokba oltottuk és szaporodási görbéjükből, életciklusukról, a sejtek életképességéről kaptunk értékes információkat. A reaktorokból mintát véve mértük azok spektrumát, amelyből számítható az optikai denzitás értéke. A 681,5 nm-hez tartozó ABS értékeket, valamint ezek változását a kiindulási értékek \%-ban határoztuk meg.

\section{Következtetések}

A kísérleteink során a $4{ }^{\circ} \mathrm{C}$-on tárolt minták esetében a gyöngyök tömege 5 hét elteltével jelentősen csökkent, tömegének $52 \%$-a elfolyósodott, a 6 . héten a gyöngyök egésze degradálódott. 
A $16{ }^{\circ} \mathrm{C}$-on tárolt mintáknál a gyöngyök tömegének $21 \%$-a folyósodott el a 7 . hétre és a teljes fizikai degradációt a 8 . héten következett be.

Mindkét raktározási mód után történő rekultivációs kísérlet sikeres volt, így megállapítható, hogy a tárolás időszakában releváns minőségváltozás nem következett be a sejtek életképességében. Így az eddigi 1 hetes tárolhatóságot átlagosan 8-szorosára tudtuk növelni.

A kísérletek jelenleg is folynak, ami a gél fázisban zajló sejt dinamikájának, illetve a gél fizikai paraméter változásainak vizsgálatával magyarázza a kísérleti eredményeket, anomáliákat. Ezzel párhuzamosan a degradációs folyamatok további késleltetésének lehetőségei és a gélben megköthető sejtkoncentrációs értékek lehetőségeinek, korlátainak meghatározása is megtörténik.

\section{Köszönetnyilvánítás}

A kutatás a TÁMOP 4.2.4.A/2-11-12012-0001 Nemzeti Kiválóság Program címü kiemelt projekt keretében zajlott. A projekt az Európai Unió támogatásával, az Európai Szociális Alap társfinanszírozásával valósul meg.

\section{Szakirodalmi hivatkozások}

[1]Abdel-Raouf, N; Al-Homaidan, A.A.; Ibraheem, I.B.M. (2012) Agricultural importance of algae, Afr J Biotechnol, 2012, 11,11648-11658.
[2]Faheed, F.A.; Abd-El Fattah, Z.: Effect of Chlorella vulgaris as biofertilizer on growth parameters and metabolic aspects of lettuce plant, J Agric Social Sci 2008, 4, 165-169.

[3] Shaaban, M.M.: Nutritional status and growth of maize plants as affected by green microalgae as soil additives, OnLine J Biol Sci. 2001, 6, 475-479.

[4] Garcia-Gonzalez, J.; Sommerfeld, M.: Biofertilizer and biostimulant properties of the microalga Acutodesmus dimorphus, J Appl Phycol 2005, 28, 1051-1061.

[5] Abd El-Motty, E. Z.; Shahin, M. F. M.; ElShiekh, M. H.; Mahmoud, M. M.: Effect of algae extract and yeast application on growth, nutritional status, yield and fruit quality of Keitte mango trees, Agric. Biol. J. N. Am. 2010, 1(3), 421-429.

[6] Abd El Moniem, E. A.; Abd-Allah, A.S.E.: Effect of Green Alga Cells Extract as Foliar Spray on Vegetative Growth, Yield and Berries Quality of Superior Grapevines, American-Eurasian J. Agric. \& Environ. Sci. 2008, 4 (4), 427-433.

[7] Shaaban, M.S.; El-Saady, A. M.; El-Sayed, A. E. B.: Green Microalgae Water Extract and Micronutrients Foliar Application as Promoters to Nutrient Balance and Growth of Wheat Plants, Journal of American Science 2010, 6(9), 631-636.

[8] Yean-Chang C.: Immobilized microalga Scenedesmus quadraicuada (Chlorophyta, Chlorococales) for long-term storage and for application for water quality control in fish culture, Aquaculture, 2000, 195. 71-80. 